\title{
Contributors to this volume and their entries
}

Amariglio, Jack, Economics, Merrimack College, North Andover, US

Poststructuralism

Backhouse, Roger E., Economics, University of Birmingham, UK

Lakatos, Novel Facts, Paradigm/Normal Science, Rhetoric

Balzer, Wolfgang, Institute for Philosophy, Logic and Wissenschaftstheorie LudwigMaximilians University, Munich, Germany

Set Theoretic Structuralism

Bausor, Randall, Economics, University of Massachusetts at Amherst, US

Time

Biddle, Jeff E., Economics, Michigan State University, E. Lansing, US

Mitchell

Blaug, Mark, Economics, University of Exeter, UK

Methodology of Scientific Research Programmes, The Positive-Normative Distinction

Boettke, Peter J., Economics, Manhattan College, US

Von Mises

Boland, Lawrence A., Economics, Simon Fraser University, Burnaby, Canada

Conventionalism, Critical Rationalism

Boulier, Bryan L., Economics, George Washington University, Washington, US

Survey Methods

Boumans, Marcel, Economics, University of Amsterdam, The Netherlands

Tinbergen

Boylan, Thomas A., Economics, University College Galway, Ireland

van Fraassen

Bradie, Michael, Philosophy, Bowling Green State University, USA

Evolutionary Epistemology

Caldwell, Bruce, Economics, University of North Carolina, Greensboro, US

Hayek, Hutchison, Situational Analysis

Callari, Antonio, Economics, Franklin and Marshall College, Lancaster, US

Althusser

Cartwright, Nancy, Centre for the Philosophy of the Natural and Social Sciences, London School of Economics and Political Science, UK

Capacities

Coats, A.W., Economics, University of Nottingham, UK

Economic History, Economics as a Profession

Cottrell, Allin, Economics, Wake Forest University, Winston-Salem, US

John Maynard Keynes, Materialism, The Socialist Calculation Debate

Creedy, John, Economics, University of Melbourne, Australia

Edgeworth

Cremaschi, Sergio, Faculty of Letters and Philosophy, University of Turin, Italy

Malthus 
The handbook of economic methodology

Cross, Rod, Economics, University of Strathclyde, UK

The Duhem-Quine Thesis, Hysteresis

Davis, John B., Economics, Marquette University, Milwaukee, US

Conventions, Ontology, Organicism, Ricardo

De Marchi, Neil, Economics, Duke University, US

Mill

Deane, Phyllis, University of Cambridge, UK

John Neville Keynes

Dow, Sheila C., Economics, University of Stirling, UK

Post Keynesianism

Emami, Zohreh, Aererno College, Milwaukee, US

Robinson

Emmett, Ross B., Economics, Augustana University College, Alberta, Canada

De Gustibus Non Est Disputandum, Knight

Evensky, Jerry, Economics, Syracuse University, US

Smith

Gilbert, Christopher L., Economics, Queen Mary and Westfield College, University of London, UK

Econometric Methodology

Goldfarb, Robert S., Economics, George Washington University, Washington, US

Survey Methods

Granger, Clive W.J., Economics, University of California at San Diego, US

Granger Causality

Hamminga, Bert, Philosophy, Tilburg University, The Netherlands

Plausibility, The Poznan Approach

Hammond, J. Daniel, Economics, Wake Forest University, Winston-Salem, US

Friedman

Hands, D. Wade, Economics, University of Puget Sound, Tacoma, US

Positivism, Reflexivity, Relativism, Rorty, Scientific Explanation, The Sociology of Scientific

Knowledge

Hargreaves Heap, Shaun, Economics, University of East Anglia, UK

Game Theory, Rational Choice

Henderson, James P., Economics, Valparaiso University, US

Whewell

Henderson, Willie, School of Continuing Studies, University of Birmingham, UK

Metaphor

Hirsch, Abraham, Economics, Brooklyn College, US

Dewey

Hodgson, Geoffrey M., Judge Institute of Management Studies, University of Cambridge, UK Emergence, Evolutionary Economics, Selectionist Arguments

Hoover, Kevin D., Economics, University of California at Davis, US

Causality, The New Classical Macroeconomics

Janssen, Maarten C.W., Economics, Erasmus University, Rotterdam, The Netherlands Aggregation, Microfoundations

Jarsulic, Marc, Economics, University of Notre Dame, US

Chaos in Economics 
Jennings, Ann L., Economics, Lafayette College, Easton, US

Veblen

Jensen, Hans E., Economics, University of Tennessee, Knoxville, US

Myrdal

Kincaid, Harold, Philosophy, University of Alabama at Birmingham, US

Methodological Individualism/Atomism, Supervenience

Knorr Cetina, Karin, Sociology, University of Bielefeld, Germany

Constructivism

Knudsen, Christian, Copenhagen Business School, Denmark

Functionalism

Lagueux, Maurice, Philosophy, University of Montreal, Canada

A Priorism, Demarcation

Lawson, Tony, Faculty of Economics and Politics, University of Cambridge, UK

Tendencies, Transcendental Realism

Mäki, Uskali, Philosophy, Erasmus University, Rotterdam, The Netherlands

As If, Ceteris Paribus, Coase, Instrumentalism, Realism, Realisticness

Mayer, Thomas, Economics, University of California at Davis, US

Monetarism

Mayer, Tom, Department of Sociology and Institute of Behavioral Sciences, University of Colorado, Boulder, US

Analytical Marxism

Milberg, William S.,Economics, New School for Social Research, New York, US

Ideology

Mirowski, Philip Economics, University of Notre Dame, US

Georgescu-Roegen, Operationalism, Probability

Mongin, Philippe, National Centre of Scientific Research and University of Cergy-Pontoise,

France

Expected Utility Theory, The Marginalist Controversy

Mongiovi, Gary, Economics, St. John's University, US

Sraffa

Morgan, Mary S., Economic History, London School of Economics and Political Science, UK Haavelmo, Models

Nadeau, Robert, Philosophy, University of Quebec, Montreal, Canada

Spontaneous Order

Nelson, Alan, Philosophy, Brandeis University, Waltham, US

Experimental Economics, Natural Kind

Nelson, Julie, A., Economics, University of California at Davis, US

Feminist Economic Methodology

Niiniluoto, Ilkka, Philosophy, University of Helsinki, Finland

Fallibilism, Induction, Truth, Truthlikeness

O'Brien, Denis P., Economics, University of Durham, UK

Robbins

O'Gorman, Paschal F., Economics, University College Galway, Ireland van Fraassen

Pettit, Philip, Research School of Social Sciences, Australian National University, Canberra, Australia

The Invisible Hand, Verstehen 
xii The handbook of economic methodology

Piimies, Jukka-Pekka, University of Helsinki, Finland and The European Parliament Ceteris Paribus

Qin, Duo, Economics, Queen Mary and Westfield College, University of London, UK Bayesian Econometric Methodology

Redman, Deborah A., George Washington University, US

Feyerabend

Reuten, Geert, Economics, University of Amsterdam, The Netherlands

Dialectical Method, Marx's Method

Rizvi, S. Abu Turab, Economics, University of Vermont, US

Utility

Rosenberg, Alexander, Honors Program, University of Georgia, Athens, US

Folk Psychology

Ruccio, David F., Economics, University of Notre Dame, US

Deconstruction

Runde, Jochen, Girton College, Cambridge, UK

Shackle, Uncertainty

Rutherford, Malcolm, Economics, University of Victoria, Canada

Commons, Institutionalism

Salanti, Andrea, Economics, University of Bergamo, Italy

Falsificationism, Pareto

Samuels, Warren J., Economics, Michigan State University, E. Lansing, US

Methodological Pluralism

Schabas, Margaret, Philosophy, University of York, Canada

Jevons

Sent, Esther-Mirjam, Economics, University of Notre Dame, US

Artificial Intelligence, Bounded Rationality, Simon

Shearmur, Jeremy, Political Science, Australian National University, Canberra, Australia Popper

Shionoya, Yuichi, Social Development Research Institute, Tokyo, Japan

Schumpeterian Evolutionism

Simon, Herbert A., Psychology, Carnegie Mellon University, Pittsburgh, US

Psychology and Economics, Simulation

Spanos, Aris, Economics, University of Cyprus, Nicosia, Cyprus

Econometric Testing

Stanfield, James R., Economics, Colorado State University, Fort Collins, US

Polanyi

Swedberg, Richard, Sociology, University of Stockholm, Sweden

Economic Sociology, Weber

Tullock, Gordon, Economics, University of Arizona, Tucson, US

Public Choice

Uebel, Thomas E., Philosophy, Logic and Scientific Method, London School of Economics and Political Science, UK

Neurath

Vanberg, Viktor J., University of Freiburg, Germany

Buchanan, Constitutional Political Economy, Rule Following

Vilks, Arnis, Institute for Statistics and Econometrics, University of Hamburg, Germany Axiomatization 
Viskovatoff, Alex, Economics, Central European University, Budapest, Hungary

Holism

Walker, Donald A., Economics, Indiana University of Pennsylvania, US

Walras

Walliser, Bernard, Ecole Nationale des Ponts et Chaussées, Paris, France

Analogy, Generalization

Whitaker, John, Economics, University of Virginia, Charlottesville, US

Marshall

Wible, James R., Economics, University of New Hampshire, Durham, US

Economics of Science, Peirce

Wilber, Charles K., Economics, University of Notre Dame, US

Economics and Ethics

Zamagni, Stefano, Economics, University of Bologna, Italy

Hicks 
